\title{
医薬品製造販売承認後の安全な適正使用
}

\author{
黒川達夫
}

\section{Post-marketing Drug Safety Measures for the Attainment of Safer and More Effective Use of Drug}

\author{
Tatsuo KUROKAWA \\ Chiba University, Graduate School of Pharmaceutical Sciences, 1-8-1 Inohana, \\ Chuo-ku, Chiba 260-8675, Japan
}

(Received September 22, 2010)

\begin{abstract}
In contrast with the 20th century's dramatic improvements in the direct and/or hazardous toxicity of drugs, indirect toxicity and/or long-term safety concerns such as relation of cancer risk and TNF-alpha receptor blockers have caused significant complexity in post-marketing surveillance (PMS) scenery. The post-marketing phase of drugs and their safety measures now appear to be much more complicated and heavier than decades ago. The spontaneous adverse drug reaction (ADR) reporting system which has been one of the main pillars of PMS measures for almost 50 years may have to be reviewed in terms of its effectiveness, and may need augmentation from medical data bases. Only a pharmacoepidemiological analysis and integration of the output with a conventional spontaneous reporting approach offers a chance to satisfy the current complex safety issues. Today's tendency toward practical saturation at medical/pharmaceutical frontiers, by regulatory authorities and safety divisions of pharmaceutical companies with ever-increasing day-to-day safety information can also be pointed out. Such phenomena may actually reduce the productivity of safety measures and also jeopardize the maintenance of an acceptable risk/benefit drug ratio. To alleviate these potential negative implications, establishment of a consortium to act as a sentinel that would gather up-to-date and essential safety information, including epidemiological data, from all sources and provide it plus recommendations to all stakeholders can be suggested. Through such activities, we could expect significant improvement of drug safety measures in post-marketing phase which would effectively cover not only new drugs but also generic and bio-simulated drugs.
\end{abstract}

Key words__adverse drug reaction; drug safety; drug monitoring system; epidemiological study; drug data base; Yakugai

\section{1. 序}

医薬品は今日の医療に欠くことのできない存在で あり，患者個人における疾病の診断，治療，QOL の改善から，これらを通じた社会福祉の向上に至る まで，極めて大きな効用と貢献をもたらしている. 一方，医薬品・医療機器は，それら製品が直接・間 接に生命の機能に影響を与えるよう設計され製造さ れる本質から，使用には副作用発現などのリスクが かならず伴うことになる。専門家による処方と調 剤，服薬指導などが求められる所以であり，また医

千葉大学薬学研究院国際臨床開発・規制科学（干2608675 千葉市中央区亥鼻 1-8-1)

現所属 : 慶應義塾大学薬学部レギュラトリー・サイエ ンス（†105-8512 東京都港区芝公園 1-5-30)

e-mail: kurotats@da2.so-net.ne.jp

本総説は, 日本薬学会第 130 年会シンポジウム MS03

で発表したものを中心に記述したものである.
薬品・医療機器使用の安全性を高め, 有効性を発揮 させるべく各種の努力がなされている. 代表的なも のは，市販後における安全性や有効な使用向上に向 けたライフスパンに及ぶ試験研究であり，また薬害 問題などを機会とした法制・制度の改善に向けた努 力である。こういつた取り組みをさらに実効あらし むるには，医薬品の市販後の安全対策や適正使用の ための制度・仕組みの整備，その適切な運用と改善 が重要である。これらについて適正使用の観点を中 心に現状, 課題と今後の方向を考察する.

\section{2. 安全性からみた医薬品の特徵}

医薬品は薬事法の第 2 条に定義され, 次の 2 点が 核心となる。すなわち：

(1) 疾病の診断, 治療又は予防に使われることを 目的とする.

(2) 身体の構造や機能に影響を与えることを目的 
とする

したがってその使用や適用は，治療の成否や望ま れた影響の多宾を始めとする本質的かつ予測困難な リスクを内包し，また誤用であるか否かにかかわら

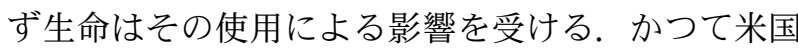
FDA の安全性問題担当官は，医薬品を「unavoidably unsafe products」と表現したが，医薬品の本質 を捉えているものと思われる。しかしこれは日用製 品（daily commodity）全般の視点からみると，医 薬品・医療機器のみにみられる特徵ではない。普段 飲用している水であっても，短時間に過大な量を摂 取すれば思わぬ生理作用を発揮し水中毒に至る。水 が極めて毒性の低い物質であり，中毒に至るために は $\mathrm{kg}$ 単位の摂取が必要となることが異なるだけ で，医薬品は $\mathrm{mg}$ あるいは $\mu \mathrm{g}$ オーダーで望まれる 生命に対する作用（薬理作用であり，望まれる作用 でなければ毒性となる）を発揮するという部分で違 いを示すに過ぎない。すなわち物質が生命に及ぼす 直接の毒性は量の概念，1つの物質の連なつた働き であり，どのようなものでも過剩に用いれば健康に 害作用を及ぼすことになる。医薬品は生理作用に及 ぼす影響が顕著であり，特徴的なものを選択し製品 の使用目的や効用として用いていることから，その リスクの側面が特記され，またそうされる必要があ る.

上記医薬品が示す直接毒性は，前世紀全体にわた る成分の改良や置き換えの努力により相当の改善が なされている，例えば往事汎用されていたクレゾー ルやフェノール，水銀・ビスマスなどの重金属やヒ 素を含有する医薬品などは，より直接毒性の低い有 機化合物やペプチド・タンパク質などに置き換えら れている。

前者に属する古典的な医薬品は各種細胞の機能全 般にわたつて影響を与え，受容体や作用機作もそれ ほご選択的，特異的というものではなかった。しか し最近開発された医薬品には，人体の免疫機能や細 胞内のシグナル伝達に影響を与えるもの（各種細胞 内キナーゼ，リガンド類縁化合物など)，生命の基 幹物質であるステロイド類の合成酵素に働きかける ものなど，その物質の持つ直接毒性とは異なる側面 で機能し，生命に対する安全性がいわゆる「量の概 念」で捉えることの難しいグループがみられるよう になっている.
これらの比較的新しい医薬品群は，その医薬品の 医療の場における適応や安全性に新たな側面をもた らしている，例えば有効性が期待できる患者の選択 や長期使用時における生命機能への影響，特定の副 作用発現リスクなどである。ロロェコキシブによる 心血管系への副作用リスクや，免疫抑制剂による将 来の腫瘍発現リスクなどが一例であり，また医薬品 による間質性肺炎など重篤な副作用が，なぜある患 者には発現し他の患者には発現しないのか，など新 たな課題がもたらされている。

\section{3. 医薬品開発段階における安全性解明の限界と} 対応

新薬や新たな治療法は，ヘルシンキ宣言にあるよ うに開発研究のいずれかの段階で必ずヒトを対象と した試験研究によりその働きを調へ，確認すること が必要である. ${ }^{1)}$ 今日の医学・薬学の長足の進歩に もかかわらず，この段階は欠くことのできないステ ップとして存在する。一方このヒト対象試験研究 は，生命として統合されたヒトに対する作用が明ら かでない化学物質・タンパク質などを投与すること から，倫理的な側面で常に緊張を孕み，可能な限り 少数の被験者で感度よく短時間に結果を得る必要が ある，その限定は何よりも優先されるが，同時にい くつかの制約をもたらす。現在のところ有効性につ いてはその時点の標準的治療法に対する力量，すな わちべネフィットに関する情報を得ることはかろう じて可能であるが，多様性に富む実践の医療の場に おける患者への適用，特にそのリスクについて完全 に予測し得る科学的デー夕基盤を用意することは困 難である，そのような安全性情報は，極論すればヒ 卜の多様性他の要因から，投与が予想されるすべて の人々に投与を終え，ようやく定まるという性質の ものであり，求めて得られるものではない。したが つて開発段階では，安全性について「何が発現した か，何が分かったか」の情報を明らかにすることは 言うまでもなく，適用された開発手法とその限界の 冷静かつ科学的な評価から，「いまだ分かっていな いことは何か」をより明瞭かつ分かり易く示し，新 薬を使用する医薬品関係者等に提供することが重要 と思われる。

\section{4. 製造販売承認後における安全対策の様相}

現行の副作用安全性情報に関する収集，評価，対 応システムや，対応する国際的な協力体制などにつ 
いては，既に優れた論文等があり，重複は避ける. 市販直後調查等の強化安全対策も同様である．その 上で，これら制度とその運営上にある現在の安全対 策やそのメカニズム，またそれらが期待通り機能す るための与件, さらに新たな薬剤疫学的なアプロー チの必要性などについて考察する.

\section{4-1. 自発的な副作用報告制度とその現状 現}

在，薬事法に基づく医薬品に関する安全性報告（こ こでは主に副作用症例報告を対象に考える）は，企 業からのものが年間約 2 万 5 千件，医療機関から直 接医薬品医療機器総合機構（PMDA）などに報告 されるものが 5 千件前後であり，国内起源の副作用 報告は合計約 3 万件前後で推移している. 企業から 報告される 2 万 5 千件の症例報告は，企業が入手し たすべての副作用症例から，未知又は重篤な副作用 等や新薬由来のケースを選択し報告されるものであ る．個別企業にしてみれば，PMDA に報告する数 の約 10 倍の症例報告を受領し，評価並びに保持し ているとされる. ${ }^{2)}$

以上に基づき粗い見積もりを試みると，官民を問 わず年間の副作用症例報告到来件数は，年間約 25 万件を上回るであろうことが分かる。一方，わが国 の医療機関（病院・診療所）は約 9 万施設で，その うち病院は約 8 千施設である。これらを総合する と，一医療機関あたり年間 3 件弱の副作用症例に遭 遇するという見かけになる．添付文書にある副作用 発現頻度に照らすと，実際には報告されていない副 作用発現症例が相当数存在すると考えることが自然 であろう。

\section{4-2. 安全性報告（副作用症例報告）は 1 日あた} り 360 件 ここで視点を安全性報告を受領し評価 する規制側に移す。 1 件の副作用症例について，平 均して第一報, 中間報告, 最終報告の 3 回の提出が あると考えると，年間約 9 万件の「直ちに評価しな ければならない症例報告」が到来すると考えられ る。これは 1 日あたり約 360 件に相当し， 1 分 20 秒毎に副作用症例報告が到来する状況となる。この うち約 300 件が企業からの法令に基づく報告，すな わち未知又は重篤な副作用報告や新薬の副作用報告 となる。このほか外国規制当局による措置報告や文 献報告の処理，使用上の注意の改訂検討や指示，医 療機器などに関する同様な作業を考えると，報告を 受ける規制側は相当な処理需要の下にあると推定で
きる，対応する医薬品企業における作業について は，規制側の事情をそのまま外挿することはできな いが，常に報告対象副作用症例の 10 倍規模を扱う という指摘からすると, これも相当な業務量に及ん でいると推定できる。 ${ }^{3,4)}$

4-3. 安全性報告（副作用症例報告）の伝達·評 価プロセスと評価者の任務副作用症例報告は通 常定められた様式に記入され，さらにその多くは電 子的データとして作成保管され，規制官庁などに報 告される，各症例報告には，性別，年齢，身長や体 重，治療対象原疾患，合併症などの基本的情報と， 原疾患や副作用に対応して体温，尿量，血圧や心拍 数などの基礎的なバイタルデータや，肝機能・腎機 能などの臨床検査值, $\mathrm{PaO}_{2}$, さらに $\mathrm{X}$ 線や $\mathrm{CT}$ 撮 影像など，疾病や副作用の詳細な経過が分かる症例 表が用意され，これが評価されることになる，例え ば背景に複数の疾患を持つ高齢の入院を要する患者 のケースなどを想定すれば明らかなように，時々刻 々投薬や呼吸管理などのインターベンションがなさ れ，また血圧の変動や不整脈，発疹などエピソード が発生することになる。これらを記述した医薬品安 全性情報（副作用症例報告）から，被疑薬とそれ以 外の併用医薬品を特定し，その被疑薬やそれ以外の 併用医薬品の最新の使用上の注意等注意喚起情報内 容を照合し，かつその時点までの類似の副作用報告 の有無や類薬の副作用状況，さらに海外における副 作用発生状況の確認などが行われ，総合することに より評価と対応の基本が形成される。これら複雑な 因果関係を安全性担当者が自らの経験や専門性に照 らし納得するまで突き詰めるプロセスを考えると， 極めて労働集約的で専門性に富み，かつ大きな使命 感を要する業務であることが分かる. ${ }^{4}$

4-4. 安全性報告（副作用症例報告）の発生とキ ャプチュア 4-3.に述べた評価対象となる安全性 報告（副作用症例報告）は，一義には情報発生源と 接する医薬品製造販売業者すなわち製薬企業により 作成される。このプロセスには，安全性情報担当者 らが医療機関等から副作用が疑われる症例情報など を入手し，担当医師・薬剤師へのインタビューやカ ルテ等からのキャプチャーを行い，これを一元的に 集めて対策の緊急性や当局報告の必要性について一 次評価を行うという作業が含まれる。また欠測値や 転帰などクエリー発生対応を始め, 医学薬学的に信 
頼できる評価が可能な「質の高い安全性報告（副作 用症例報告)」に作り起こす作業も安全対策の一環 であり，これらを日夜進めている安全性担当者の業 務や，当該企業における責任と負担は軽いものでは ない.

4-5. 安全性確保業務の性質と担当者に求められ る資質これまで医薬品使用の実態や患者・医療 側の事情，評価・処理のステップなど，いずれも既 に相当な労働集約的かつ高度に専門的な作業となつ ていることを述べた，繰り返しになるが，安全性担 当者には個別症例になされたインターベンションと イベント, エピソードについての統合的理解力, 多 数の併用医薬品と原疾患の症状や推移の意味づけ, 起こり易い合併症や臨床検査值からの突き合わせ, 生理・病理学的な矛盾の有無など複雑な要素を的確 に考察し, さらに当該医薬品安全対策の歴史や経過 まで考慮に入れ，これらすべてを過不足なく総合し た形で安全性を評価できる能力が求められる，また これら一連の思考展開と対応は時間的な遅れなく行 われなければならず，緊急性の判断力なども必要で あり，十分にトレーニングされ経験を積んだ専門家 の継続的養成と，これら安全対策専門家の安全対策 プロセス全般への関与は，強調されてされ過ぎるこ とはないと思われる。

4-6. 自発的報告制度の特徵と限界 ここで現 在の安全対策の柱となっている自発的報告制度の特 徵や検出能力を, 医薬品の投与から時間を置いて発 生する安全性問題や, 原疾患 - 症状に近い副作用症 状, 転帰と機作の連結が簡単でない副作用・安全性 問題を例に吟味したい. 古くはACEインヒビター による空咳の問題，また薬害事例ではヒト凍結乾燥 脳硬膜移植によるCJD 発現のケース（注：交通事 故を原疾患・既往歴とする症例が多数含まれていた が，これは頭部外傷受傷後の開頭外科手術における ヒト凍結乾燥硬膜移植が感染源であったことを示し ている）などでは，自発的副作用（CJDの場合， 感染）報告システムはこの深刻な安全性問題の検出 にほとんど貢献できていない。安全性問題全般を文 献やレポート, 症例報告などにより長期のスパンで 観測（observation）する専門家の存在や，ターゲ ットを決めた薬剤疫学的な取り組みが自発的副作用 報告の仕組みを補う形となるが，この部分はこれま でわが国で最も手薄であったところである.

\section{5. 現在の医薬品安全対策のパラダイムとその限} 界

4.より, 現在の副作用症例の自発的な報告を基 盤とする安全対策は, 方法論として既に相当成熟し たものであることが分かる.このシステムの基本形 態は 1960 年代のサリドマイドによる薬害被害を契 機に，WHO 国際ドラッグモニタリング制度が設立 され，この活動の下に各国にドラッグモニタリング システムが設置され, 多くの成果をあげてきた.

しかしわが国における制度基盤は，1967 年に活 動が開始されて既に半世紀近く経過し, 現在の情報 量, 情報収集の流れや評価の各ステップからみて, 少なくともわが国では飽和に近い状況になってい る.この 50 年の間に医療の第一線における医薬品 の態様や国民の疾病構造, さらに情報周辺科学 ・ サービスなど大きく変化する中で, 安全対策の基盤 を「自発的な副作用症例報告制度」に置き続けるこ とが最善の答えであるか，真剣な検討が必要であろ う。具体的な安全性問題も医薬品の直接の作用から 離れ，市販後段階で思わぬ角度からリスクを顕わに する安全性問題が発生し，また懸念される，現在の パラダイムのみに頼り，これらの制度を今後いくら 強化しても, 安全性向上について飛躍的な成果を望 むことは困難と思われる。これは単に検出感度や見 落としだけでなく, 制度飽和による費用対効果の低 下や既に多大なリソースが投入されている点からみ ても同様と思われる.

\section{6. 医薬品情報需要者側の事情}

6-1. 医療の第一線における医薬品情報の過剩と 飽和医療用医薬品について夕れば, 安全対策関 連情報の一義の消費者は医療従事者である. 現在の 医薬品関連安全性情報の伝達は主として医薬品添付 文書の使用上の注意の改訂や緊急安全性情報の発出 などに依拠しており，その一方で医療従事者からみ た情報入手源は医薬品製造販売業者のメディカルリ プレゼンタティブ（MR）とされている. ${ }^{5)}$ 年間の 添付文書改訂は PMDA の関与があるものだけでも 200 件前後であり，これらは通常追加又は修正され

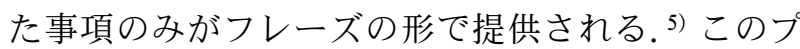
ロセスが目的を達する与件は「一般に医療従事者 は, 日々処方・調剂される医薬品全般について, そ の医薬品情報の内容, 項目の重要性や臨床における 優先性などについて既に十分理解し，基礎を備えて 
いるので，提供される安全性情報は追加修正の部分 のみで足りる」という仮説である．現実の医薬品数 や毎日供給される情報量からみて，また日々の医療 の第一線における業務量等からみて果たしてこの与 件や仮説が成立するか否か，一度振り返り評価する 必要があると思われる。また評価の結果，一層の改 善や工夫が必要となれば，例えば医学・薬学の卒 前・卒後教育などの場を活用し，専門家として生涯 にわたり必要な研鑽を支える柱としての基本を準備 させるなど，改善が必要と思われる.

6-2. 社会心理学的なアプローチと可用性ヒュー リスティック 一般に通常の業務に反映されるよ うな，すなわち記憶に残り意識されるための最も効 果的な情報伝達手段は，個人個人，1 対 1 対面によ る情報提供とされる。これは前述の「主な医薬品情 報の入手源は MR とする回答が最も多かった」と する調査結果と一致する。しかし同時にこの伝達方 法は生産性が低く，また MR は所属する企業にロ イヤリティを持つことは避けられない，安全性問題 についてみれば，MRの訓練や活動がすべての問題 点を改善すると結論するのは早計であろう.

医薬品安全性情報の所期の目的，すなわちあらず もがなの副作用・安全性問題の回避は，関連する安 全性情報が受容者に達し受け止められ，理解と共感 の中で日常の業務活動に反映され，最終的に処方の 変更，患者服薬行動の変化や健康異常（副作用の初 期症状など）の報告，受診などに結びつくことによ って達成される。このプロセスは具体的に医療機関 や家庭にある専門家や患者個人の行動を変えるこ と，またある行動をとること，行動の意思決定を促 すという過程が入る.これらの動的な過程を振り返 ると，これまであまり関心が払われてこなかった領 域で医薬品適正使用に役立つと思われるサイエンス に社会心理学がある。詳説は他書におくが，例えば 「可用性ヒューリスティック (heuristic)」という心 理学的特徴を挙げて一例としたい.

可用性 Heuristic とは，例えばテレビ番組などで 繰り返し同一の情報に接していると，そこで主張さ れていることが個人の思い出され易い（可用性の高 い）記憶となり，知識や客観的事実や認識と離れた 行動や選択，意思決定となることがある，とするも のである，例えばテレビ番組などで繰り返し「バナ ナが肥満対策によい」という情報に接すると，その
情報や主張が思い出され易い記憶となって残る。こ れが第一段階で，次に例えば果物店やジュースコー ナーなどバナナを目にする機会の際に「バナナで体 重が減るという客観的な事実は知られていない」と しっかり認識しているにもかかわらず，思い出し易 い記憶すなわち「バナナは肥満対策によい」に影響 され，バナナを手に取る，という心理学的機作であ る。医薬品においては例えば「○○は肝障害のおそ れがあるので，定期的に検査を受けるようにす心゙ き」と繰り返し報道されると，○○の使用を自己判 断で止める現象などが説明されると思われる. ${ }^{6)} こ$ れからもインターネットやテレビ報道などで，医薬 品の安全性関連情報などが正誤や根拠と関係なく短 時間に大量に提供されるケースは避けられないと思 われ，適正使用を考える際注目し，準備しておくべ き学問領域であろう。

\section{7. 今後の医薬品製造販売後の安全な適正使用に} ついて

最近の医学薬学の進歩は, 医薬品の作用機作など に大きな変化をもたらし，患者構成や疾病構造の変 化と相まって医薬品の安全性向上は多様かつ複雑な 問題となっている，今後，製造販売後の安全な適正 使用を一層推進するためには，現在までの制度仕組 みに加え新たな工夫を組み込むことが必要である. 現在の安全対策のワークホースである自発的な副作 用報告システムが，半世紀近く大きな原理的進化を 得ることなく使われ続けてきたことを述べたが，こ のシステム・考え方の限界を超える新しい取り組み の導入が急がれる。

7-1. 薬剤疫学的な検討を可能とするデータベー スの構築と公開現在の医療は，医薬品使用を始 め多くの介入がなされ，様々なイベント・エピソー ドを生じながらこれらを踏まえて展開される。医薬 品も生命や細胞機能の根源に近い部分に作用する医 薬品が現れ，生命として統合され存在する個体に対 するこれらの医薬品の影響や経時的な効果など，い まだ十分知られていない領域が少なくない。現代汎 用されつつある最先端の医薬品について，その安全 性情報の全容を的確に検出し，不要な遅れなく対応 するには自発的な副作用報告システムを頼りとする だけでは自ずから限界があると思われる。この限界 を乗り越えるためには，個々の患者について使用さ れた医薬品などすべてのインターベンションと，病 
状や疑われる副作用などのイベント・エピソードを 網羅的かつ経時的に記録収載する薬剤疫学的なデー タベースの確立と応用が役立つと思われる. 現在, 国においてその確立のための具体的かつ積極的な取 り組みがなされていることは大きな希望を与えるも のである. ${ }^{7)}$ その際，そのようなデータベースは デー夕保護等必要な情報としての安全確保を図った 上で，広く公開することが重要と思われる。それに よって初めて多数の角度からの効果的なシグナル検 出が行われるものと確信するからである。

\section{7-2. 安全対策の生産性の向上 現在安全対策} の基礎として寄与する自発的な副作用報告システム は，将来薬剂疫学的なデータベースが実用化された としてもその重要性は変わらず，むしろ患者・医療 消費者からの直接の報告導入など，新たな役割も担 うものと思われる。しかし原理や機能は既に成熟段 階を迎え，多大な人的，財政的リソースを要する営 みになっていることを論じた，米国で展開されてい るREMS などでは報告義務を总った場合に相当な 罰則を用意するなど強化が進められている。しかし 6. までに述べたように，このままの形でこれ以上 従事する組織や部署を叱咜激励しても，成果や生産 性向上の余地は少ないと考える，費用は究極的には 医薬品価格に反映される形となる，わが国経済の長 期かつ構造的低落傾向を考え合わせると，市販後安 全対策においても少ないリソースとコストで効果や 生産性を上げていく工夫が必要となってきた現実も 直視されなければならない，安全性の向上と引き替 えに患者や社会にとってアフォーダビリティやアバ イラビリティに乏しい医薬品ばかりになってしまっ ては「何のための安全性か」ということになるから である。

7-3. 公益団体 · コンソーシアム形式による安全 性情報（副作用症例報告）収集・評価·報告システ ムの確立 現在, 医薬品企業では各社で相当の員 数の安全対策要員を擁し，それぞれ専門家を養成し て法的義務の達成を図っている。これは多数の報告 対象品目を持つ企業などでは既に数百人の専任から
なる組織が必要とされる。 ${ }^{2,3)}$ 仮にこの業務を非営利 かつ公益性の高い団体（又は大学・教育研究機関や 研究所）などに集約し，様々な領域の専門家や経験 者などによる各症例報告の同時多方面からの評価検 討，安全対策案の検討，また必要な規制官庁への報 告や対応などが一挙に行われるようになれば，現在 の自発的な副作用症例報告が直面する問題はかなり 緩和されるように思われる。 リソースの活用と正確 性・迅速性の向上のほか，現在普及が進められてい るジェネリック医薬品，バイオシミラー医薬品など の安全性向上や普及などにも貢献は大きいと思われ る。さらに7-1.に述べた薬剤疫学的なデータベー スを活用した精密かつ長期にわたる分析や，安全性 オブザベーションについても，このような組織があ れば容易に実現することができよう。人材育成につ いてみても卒前・卒後教育への貢献など絶好の機 会・場所となる．現行の仕組み・予算や法制などこ とは単純ではないが，関係各位のご理解と実現に向 けたご助言やご批判をお願いし，この稿を終えたい．

\section{REFERENCES}

1) Olson M. K., J. Health Econ., 27, 175-200 (2008).

2) Ministry of Health, Labour and Welfare: $\langle$ http://www.mhlw.go.jp/shingi/2008/05/txt /s0523-1.txt $\rangle$, cited 7 April, 2011.

3) Ministry of Health, Labour and Welfare: 〈http://www.mhlw.go.jp/shingi/2008/06/txt /s0630-1.txt $\rangle$, cited 7 April, 2011.

4) Ministry of Health, Labour and Welfare: 〈http://www.mhlw.go.jp/shingi/2010/01/dl/ s0118-12c.pdf $\rangle$, cited 7 April, 2011.

5) Ministry of Health, Labour and Welfare: 〈http: // www.mhlw.go.jp / shingi / 2009/03/ s0317-7.html , cited 7 April, 2011.

6) Kubota K., Kurokawa K., Nippon Iji Shinpo, 3917, 69-72 (1999).

7) Ministry of Health, Labour and Welfare: 〈http: // www.mhlw.go.jp / shingi / 2010/04/ s0428-8.html $\rangle$, cited 7 April, 2011. 